\title{
A 20th-century record of naphthalene in an ice core from Svalbard
}

\author{
Jari VEHVILÄINEN, ${ }^{1,2}$ Elisabeth ISAKSSON, ${ }^{3}$ John G. MOORE ${ }^{1}$ \\ ${ }^{1}$ Arctic Centre, University of Lapland, P.O. Box 122, FIN-96101 Rovaniemi, Finland \\ E-mail: jari.vehvilainen@urova.fi \\ ${ }^{2}$ Laboratory of Analytical Chemistry, University of Helsinki, FIN-00014 Helsinki, Finland \\ ${ }^{3}$ Norwegian Polar Institute, Polar Environmental Centre, $\mathcal{N}-9296$ Tromsø, Norway
}

\begin{abstract}
Measurements of polycyclic aromatic hydrocarbons in a $122 \mathrm{~m}$ ice-core record from Lomonosovfonna, Svalbard, showed only naphthalene (NAP) to be detectable with our small (average $56 \mathrm{~g}$ ) sample sizes. Prior to the 1930s, NAP was below our determination limit, but its concentration increased to a peak in the 1980s. In general, concentrations $\left(5-53 \mathrm{ng} \mathrm{kg}^{-1}\right)$ are six times lower than for Agassiz Ice Cap, Canada, but about 50 times higher than in Greenland. Correlation of NAP with physical and chemical parameters in the core strongly suggests wintertime deposition of NAP with Arctic haze. Post-depositional effects of periodic melting appear slight, probably due to the hydrophobic nature of NAP. The contribution made to the record by small coal-mining activities on Svalbard appears to be small compared with anthropogenic emissions from long-range sources.
\end{abstract}

\section{INTRODUGTION}

The relatively high anthropogenic pollution levels in Svalbard biological life have been documented and discussed during the last few decades (e.g. Bernhoft and others, 1997). Many organic contaminants, including polycyclic aromatic hydrocarbons (PAHs), show higher concentrations in the Arctic than the global background (Nilsson, 1997). However, because PAHs do not accumulate for long periods of time in living tissues, they have not received as much attention as many other organic pesticides, despite the fact that many $\mathrm{PAHs}$ are carcinogenic or mutagenic (e.g. Zedeck, 1980; Barrie and others, 1992).

Natural sources of PAHs include biomass burning, volcanoes, natural losses or seeps of petroleum or coal deposits and diagenetic production in soils and sediments (e.g. Wakeham and others, 1980; Baek and others, 1991; Macdonald and others, 2000; Masclet and others, 2000). Many of the PAHs, including naphthalene (NAP), have anthropogenic sources, chief among which are the combustion of organic fuels and materials (Baek and others, 1991). The emission of PAHs from anthropogenic sources has increased dramatically along with the increased combustion of fossil fuels during the past century (Wakeham and others, 1980).

PAHs are semi-volatile and can be transported many thousands of kilometers (Macdonald and others, 2000), mainly in the particulate form over long distances in the atmosphere (e.g. Jaffrezo and others, 1994; Mascalet and Hoyau, 1994). The residence times of PAHs in atmosphere are variable, ranging from hours to several months (Masclet and others, 2000), and are strongly dependent on temperature and chemical species. NAP becomes the increasingly predominant $\mathrm{PAH}$ in colder, more polar environments due to global fractionation and cold condensation (Wania and Mackay, 1993; personal communication from A. J. Peters, 2000).

PAHs are continuously measured every week in air samples at Ny Ålesund, Svalbard (Tørseth and others, 1999) (Fig. 1).
There is a clear seasonal variation, with the highest concentration during the winter months and early spring, in direct response to the long-range transport of air masses from the Eurasian continent (Arctic haze). NAP and biphenyl contribute to $70 \%$ of the measured PAH compounds in Ny Ålesund.

In the Arctic atmosphere, practically all PAHs are adsorbed on particles (Masclet and Hoyou, 1994). In the snowpack, PAHs (including NAP) can be preserved for long periods, especially those adsorbed on particles (Masclet and others, 2000). Until recently, studies of organic compounds in snow and ice have been limited because of the large samples required. By presenting a 400 year long $\mathrm{PAH}$ record from a

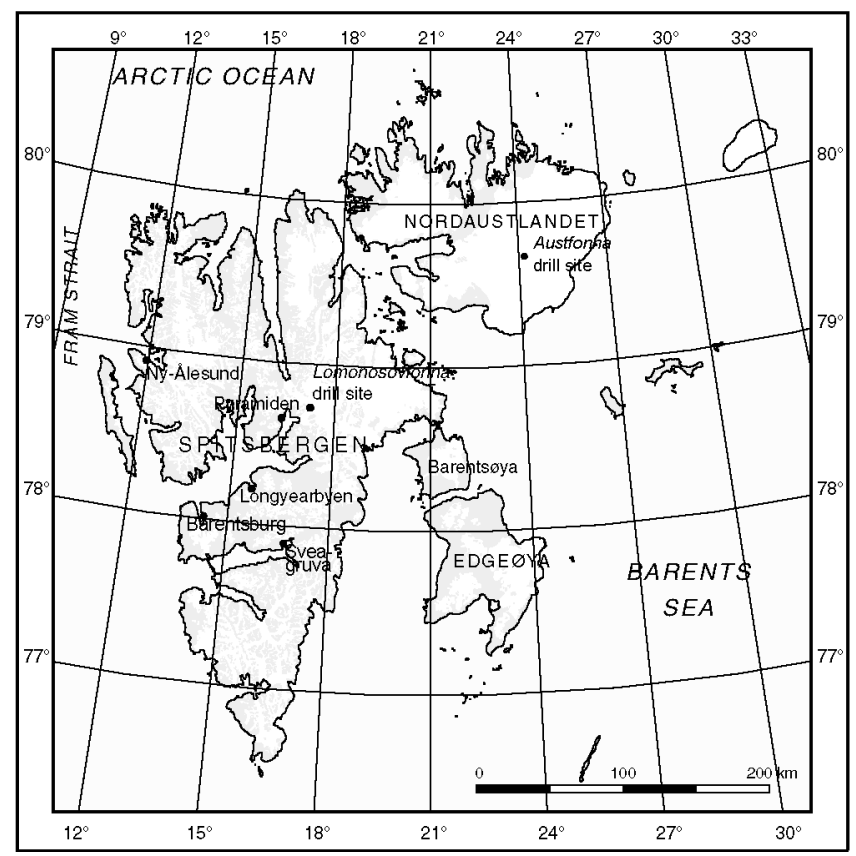

Fig. 1. Map of Svalbard with the geographical names mentioned in the text. 
Greenland ice core, Kawamura and others (1994) showed that it is possible to develop long records of PAH from ice cores. Also, Jaffrezo and others (1993, 1994), Masclet and Hoyau (1994) and Masclet and others (2000) have studied snow and ice from Greenland. More recently (Peters and others, 1995; personal communication from A.J. Peters, 2000), a 200 year record in snow from Agassiz Ice Cap, Canada, has been studied. PAH studies of ice from Svalbard have not been presented before, and in this paper we present a record of NAP, spanning the last century from Lomonosovfonna, Svalbard (Fig. 1).

Lomonosovfonna is remote from major pollution sources, with the exception of coal mines at Barentsburg, Sveagruva, Pyramiden (the closest, $35 \mathrm{~km}$ from the drill site, in operation between 1947 and 1998) and Longyearbyen (the largest settlement, $100 \mathrm{~km}$ from the drill site, in operation since 1911) (Fig. 1).

\section{DATING OF IGE GORE AND PRESERVATION OF THE RECORD}

In 1997, a $122 \mathrm{~m}$ ice core was retrieved from the summit of Lomonosovfonna, the highest icefield in Spitsbergen (1255 $\mathrm{m}$ a.s.l.) (Isaksson and others, 2001). The time-scale of the core was based on a simple age-depth model based on pure shear (Nye, 1963) and tied with the known dates of prominent reference horizons (1963 radioactive layer and 1783 Laki (Iceland) volcanic acid layer). Studies so far indicate that the core contains a reliable record of isotope and chemical concentrations that can be successfully used in climate studies (Jauhiainen and others, 1999; O’Dwyer and others, 2000; Isaksson and others, 2001; Pohjola and others, 2002).

Analysis of other chemical species suggests that the distribution of NAP at Lomonosovfonna may be slightly altered by meltwater percolation. The degree of redistribution of the different chemical species by meltwater seems to be dependent on their physical chemistry (Pohjola and others, 2002). Acids are vulnerable to percolation in the snowpack, but it is limited to two or three annual layers and run-off is zero. Sea salts and insoluble dust appear to be less mobile.

\section{ANALYTIGAL PROGEDURE}

In an initial analysis, 16 commonly analyzed PAHs were measured (cf. Peters and others, 1995), but NAP alone was chosen for later work since no other PAHs were detected in the small sample size available (average $55.6 \mathrm{~g}$ ). Thirty-three ice-core samples at $6.05-104.55 \mathrm{~m}$ depth and four ice blanks were cleaned by removing the outer $5-20 \mathrm{~mm}$ of the ice core, packed in polyethylene plastic bags in a cold room under a laminar hood at about $-20^{\circ} \mathrm{C}$ (Jauhiainen and others, 1999) and transported to the chemical laboratory in Rovaniemi, Finland, in frozen condition. Ice blanks were prepared from frozen ultra-pure water "cores" that were then processed identically to the real ice cores. Additionally a set of six ultra-pure "water blanks" were prepared in the analytical laboratory for further assessing contamination and instrument detection and determination limits. Ice samples $(34-81 \mathrm{~g})$ were transferred to ultra-pure glass bottles and melted in a laminar hood at room temperature. An internal standard (ISTD) was added to the melted samples. Samples were extracted twice with $2 \mathrm{~mL}$ of hexane using a mechanical stirrer. The hexane fraction was collected and reduced in volume by air
Table 1. NAP concentrations in blanks

\begin{tabular}{cccc}
\hline Type & Set & $\begin{array}{c}\text { Concentration }^{3} \\
\mathrm{ng} \mathrm{kg}^{-1}\end{array}$ & $\begin{array}{c}\text { Average concentration }^{4} \\
\mathrm{ng} \mathrm{kg}^{-1}\end{array}$ \\
\hline WB & 1 & 14.4 & \\
WB & 1 & 13.9 & \\
WB & 1 & 14.6 & \\
IB & 1 & 14.8 & \\
IB & 1 & 13.8 & \\
& 1 & & \\
WB & 2 & 21.3 & \\
WB & 2 & 21.1 & \\
WB & 2 & 22.3 & \\
IB & 2 & 20.8 & \\
IB & 2 & 22.1 & \\
& 2 & & \\
\hline
\end{tabular}

\footnotetext{
${ }^{1}$ Type of blank: $\mathrm{WB}=$ water blank, $\mathrm{IB}=$ ice blank.

${ }^{2}$ Number of analytical set.

${ }^{3}$ The concentration of the individual blank.

${ }^{4}$ Average concentration of the set.
}

blow-down to a final volume of $50 \mu \mathrm{L}$ to analyze PAHs. Samples were analyzed by high-resolution gas chromatography with mass spectrometry. The injection volume was $2 \mu \mathrm{L}$ and measured in single-ion-monitoring-mode. PAHs were quantified relative to ISTD and the calibration curve. A recovery study, at somewhat higher concentrations than we find here, found that $94 \%$ of NAP was extracted by this method. The detection limit for NAP was $1 \mathrm{pg} \mu \mathrm{L}^{-1}$ of the extract, which resulted in a theoretical-method detection limit of $1 \mathrm{ng} \mathrm{kg}^{-1}$ of ice. The instrument detection limit is defined as the concentration of injected analy te that produces a peak with a signal-to-noise ratio $(\mathrm{S} / \mathrm{N})$ of 3 , and the determination limit as that which produces a $\mathrm{S} / \mathrm{N}$ of 10 . However, in the real samples the detection and determination limits were defined as 3 and 10 times (respectively) the standard deviation of both the ice and water blank-sample results. The average of blank samples was also subtracted from the results of NAP, which represents contamination during subsampling, sample preparation and analyses. The average blank value in the first set of samples was $14.3 \mathrm{ng} \mathrm{kg}^{-1}$, and in the second set $21.5 \mathrm{ng} \mathrm{kg}^{-1}$ (Table 1).

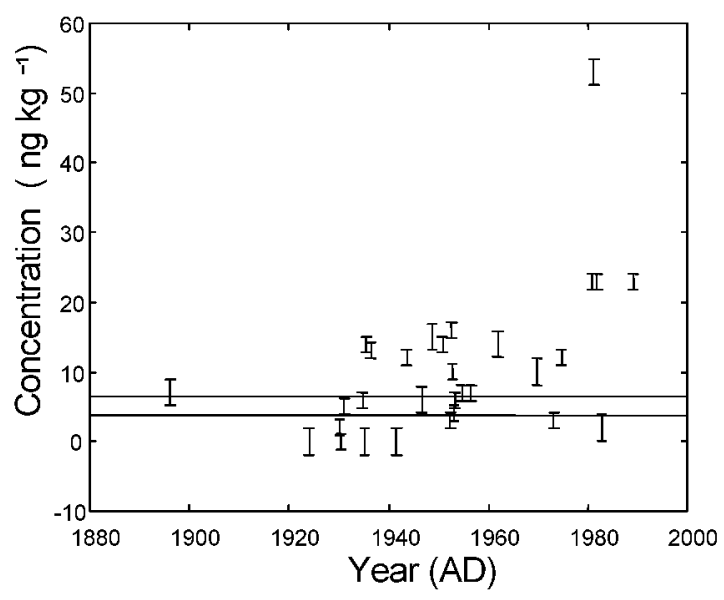

Fig. 2. NAP concentration along the Lomonosovfonna ice core. The error bars shown are the detection limits from Table 1. The determination limits for the two sets of samples are shown as the two horizontal lines on the plot. Dating is from the Nye time-scale. 
NAP concentrations in the samples were $0-53 \mathrm{ng} \mathrm{kg}^{-1}$ (average $10 \mathrm{ng} \mathrm{kg}^{-1}$ ) over the period of the last century (Table 2; Fig. 2). The NAP data showed very low concentrations up to the mid-1930s, with higher values around 1980. The overall pattern is in general agreement with the increase and then stabilizing of $\mathrm{SO}_{2}$ emissions in Europe and North America (Lefohn and others, 1999) and the aerosol record from $\mathrm{Ny}$ Ålesund (Tørseth and others, 1999). However, this general picture is also consistent with the increase during the late 1940s of the population and mining activities in Svalbard (Arlof, 1996).

NAP was the most abundant PAH compound in snow and ice cores from the Canadian Arctic (Peters and others, 1995), while other PAHs seem to be more common in Greenland (Jaffrezo and others, 1994). A. J. Peters (personal communication, 2000) found average values of NAP at Agassiz Ice Cap much higher than in Lomonosovfonna (60 and $10 \mathrm{ng} \mathrm{kg}^{-1}$, respectively), and a very high concentration in the 1960s (up to $640 \mathrm{ng} \mathrm{kg}^{-1}$ ) which is 12 times the Lomonosovfonna maximum which occurred in the 1980s. However, we have only two samples in the 1960s, so we may not have sampled the peak. Jaffrezo and others (1994) reported concentrations in Greenland with much lower levels ( $\max .0 .5 \mathrm{ng} \mathrm{kg}^{-1}$ ).

Correlation of the results of the NAP analysis with ions, oxygen isotopes and density analyzed in the ice core (Table 3) may provide insight into the origins and post-deposition processes of NAP in the core. For 15 samples we have ion chemistry and density data from samples taken at exactly the same depth as the NAP samples, while for the others we have data from samples from within $5 \mathrm{~cm}$ of the NAP samples. The correlation was in general better for the samples taken at the same depths (Table 3) than for the samples where we calculated mean chemistry (based on all samples within $5 \mathrm{~cm}$ of the NAP sample). We computed an ion balance - therefore giving the $\mathrm{H}^{+}$concentrationonly for the samples with chemical data for the same depth.

As expected, there is a significant correlation with depth and consequently age. There are significant correlations between NAP, $\mathrm{NH}_{4}^{+}, \delta^{18} \mathrm{O}, \mathrm{Cl}^{-}$and $\mathrm{H}^{+}$at the $99 \%$ level. NAP is also correlated at the $95 \%$ level with $\mathrm{NO}_{3}{ }^{-}$and with density (which varies rapidly) for the 15 same-depth samples. Arctic haze is probably responsible for a substantial part of the transport of NAP (Jaffrezo and others, 1994), so we expect the best correlations with other Arctic-haze ions. This seems to be the case for $\mathrm{NH}_{4}{ }^{+}$and to a degree $\mathrm{NO}_{3}{ }^{-}$.

Most surprisingly, NAP is not correlated with either $\mathrm{SO}_{4}{ }^{2-}$ or the non-sea-salt $\mathrm{SO}_{4}{ }^{2-}$. There might be several reasons for this, and without high-resolution data on species across several seasonal cycles we are limited to suggesting two possibilities. Sulphate is one of the first ions to migrate when meltwater is introduced (Davies and others, 1982), and may therefore have been relocated in the snow at Lomonosovfonna (Pohjola and

\begin{tabular}{|c|c|c|c|c|c|}
\hline $\begin{array}{c}\text { Depth } \\
\text { m }\end{array}$ & Date & $\begin{array}{c}\text { Real } \\
\text { concentration }^{1} \\
\mathrm{ng} \mathrm{kg}^{-1}\end{array}$ & $\begin{array}{c}\text { Analytical } \\
\text { concentration }^{2} \\
\mathrm{ng} \mathrm{kg}^{-1}\end{array}$ & $\begin{array}{c}\text { Detection limit } \\
\mathrm{ng} \mathrm{kg}^{-1}\end{array}$ & $\begin{array}{c}\text { Determination } \\
\text { limit }^{4} \\
\mathrm{ng} \mathrm{kg}^{-1}\end{array}$ \\
\hline 6.05 & 1989.1 & 23 & 23 & 1.3 & 4.4 \\
\hline 9.35 & 1982.8 & 2 & & 1.9 & 6.5 \\
\hline 9.80 & 1981.8 & 23 & 23 & 1.3 & 4.4 \\
\hline 10.05 & 1981.2 & 53 & 53 & 1.9 & 6.5 \\
\hline 10.15 & 1981.0 & 23 & 23 & 1.3 & 4.4 \\
\hline 13.35 & 1974.7 & 12 & 12 & 1.3 & 4.4 \\
\hline 14.00 & 1973.2 & 3 & & 1.3 & 4.4 \\
\hline 15.75 & 1969.8 & 10 & 10 & 1.9 & 6.5 \\
\hline 19.15 & 1961.9 & 14 & 14 & 1.9 & 6.5 \\
\hline 21.10 & 1956.6 & 7 & 7 & 1.3 & 4.4 \\
\hline 21.80 & 1954.7 & 7 & 7 & 1.3 & 4.4 \\
\hline 22.25 & 1953.3 & 6 & 6 & 1.3 & 4.4 \\
\hline 22.30 & 1953.2 & 4 & & 1.3 & 4.4 \\
\hline 22.40 & 1952.9 & 10 & 10 & 1.3 & 4.4 \\
\hline 22.45 & 1952.7 & 16 & 16 & 1.3 & 4.4 \\
\hline 22.55 & 1952.4 & 3 & & 1.3 & 4.4 \\
\hline 23.15 & 1950.9 & 14 & 14 & 1.3 & 4.4 \\
\hline 24.00 & 1948.8 & 15 & 15 & 1.9 & 6.5 \\
\hline 24.67 & 1946.7 & 6 & & 1.9 & 6.5 \\
\hline 25.80 & 1943.6 & 12 & 12 & 1.3 & 4.4 \\
\hline 26.45 & 1941.7 & 0 & & 1.9 & 6.5 \\
\hline 28.15 & 1936.5 & 13 & 13 & 1.3 & 4.4 \\
\hline 28.50 & 1935.6 & 14 & 14 & 1.3 & 4.4 \\
\hline 28.65 & 1935.2 & 0 & & 1.9 & 6.5 \\
\hline 28.80 & 1934.7 & 6 & 6 & 1.3 & 4.4 \\
\hline 29.95 & 1931.1 & 5 & 5 & 1.3 & 4.4 \\
\hline 30.15 & 1930.5 & 0 & & 1.3 & 4.4 \\
\hline 30.25 & 1930.1 & 2 & & 1.3 & 4.4 \\
\hline 32.20 & 1923.9 & 0 & & 1.9 & 6.5 \\
\hline 40.85 & 1896.2 & 7 & 7 & 1.9 & 6.5 \\
\hline 60.21 & 1815.8 & 0 & & 1.9 & 6.5 \\
\hline 70.45 & 1764.5 & 0 & & 1.9 & 6.5 \\
\hline 92.65 & 1609.9 & 0 & & 1.9 & 6.5 \\
\hline 104.55 & 1475.6 & 0 & & 1.9 & 6.5 \\
\hline
\end{tabular}

${ }^{1}$ Real concentration (blank-corrected results).

${ }^{2}$ Analytical concentration (corrected data that are also bigger than determination limit).

${ }^{3}$ Detection limit $=$ zero concentration +3 times standard deviation.

${ }^{4}$ Determination limit $=$ zero concentration +10 times standard deviation.

others, 2002). However, this would also be true of $\mathrm{H}^{+}$and $\mathrm{NO}_{3}{ }^{-}$. Another possibility is that NAP and $\mathrm{SO}_{4}{ }^{2-}$ are relocated within the ice in a similar way to the observed migration of MSA and non-sea-salt $\mathrm{SO}_{4}{ }^{2-}$ (Mulvaney and others, 1992), or $\mathrm{NO}_{3}{ }^{-}$and non-sea-salt $\mathrm{SO}_{4}{ }^{2-}$ (Röthlisberger and others, 2000).

Arctic haze is a wintertime phenomenon, so if the ions are preserved in the snowfall without redistribution, they will be in isotopically lighter winter snow: this is observed with the significant anticorrelation of NAP with $\delta^{18} \mathrm{O}$. The observation that $\mathrm{H}^{+}$is less well correlated with $\delta^{18} \mathrm{O}$ also suggests that NAP remains more localized in the ice than acids. $\mathrm{As} \mathrm{Cl}^{-}$is a sea-salt ion, it peaks during periods of storminess, and a winter peak is to be expected, again sup-

Table 3. Correlation coefficients of $\mathcal{N A P}$ and $H^{+}$with other core parameters

\begin{tabular}{|c|c|c|c|c|c|c|c|c|c|c|c|c|c|c|c|c|}
\hline & $\mathcal{N}$ & Date & Depth & Density & $C T$ & $\mathrm{NO}_{3}^{-}$ & $\mathrm{SO}_{4}^{2-}$ & $M S A$ & $\mathrm{NH}_{4}^{+}$ & $\kappa^{+}$ & $C a^{2+}$ & $\mathrm{Mg}^{2+}$ & $\mathrm{Na}^{+}$ & $\mathcal{N A P}$ & $\delta^{18} \mathrm{O}$ & $H^{+}$ \\
\hline NAP & 30 & -0.54 & 0.51 & 0.09 & 0.28 & 0.23 & 0.12 & -0.01 & 0.35 & 0.11 & -0.12 & -0.03 & 0.09 & 1.00 & -0.33 & - \\
\hline NAP & 15 & -0.52 & 0.49 & 0.28 & 0.47 & 0.29 & 0.20 & 0.06 & 0.41 & 0.06 & -0.11 & 0.11 & 0.16 & 1.00 & -0.37 & 0.31 \\
\hline $\mathrm{H}^{+}$ & 15 & -0.29 & 0.33 & 0.20 & 0.43 & 0.58 & 0.89 & 0.79 & 0.25 & 0.22 & -0.15 & 0.41 & 0.21 & 0.31 & -0.21 & 1.00 \\
\hline
\end{tabular}

Notes: Bold entries are significant at the $99 \%$ level and italicized entries at the $95 \%$ level. $N=15:$ significance $99 \%=0.35,95 \%=0.28 ; N=30$ : significance $99 \%=0.24,95 \%=0.20$. 
porting the notion of relatively little sea-salt-ion translocation in the core. NAP is also hydrophobic, especially compared with $\mathrm{H}^{+}$or $\mathrm{SO}_{4}{ }^{2-}$, and so may be expected to resist movement by percolating meltwater. Although meltwater may percolate 2-3 annual layers, it is clear that most of the meltwater must refreeze within the previous winter layer to preserve the seasonality we observe in both isotopes and ions (Isaksson and others, 2001; Pohjola and others, 2002). The filling of pore space in the spring/winter snow by melting summer snow leads to spring layers having higher density than other layers, giving the correlation of NAP with density. We may also speculate that the changes in ice fabric may prevent percolation via changes in grain-size and capillarity associated with rime layers or depth hoar, leading to a preference for refreezing in the spring layer.

One other possible significant post-deposition effect is revolatilization in the snowpack and loss after deposition (Masclet and other, 2000). The samples closest to the surface are below ice layers, and the concentrations do not show any large increase near the surface, so this effect cannot be seen in our data.

One difficult problem in interpreting NAP data from Svalbard is the probable existence of local sources of emission associated with coal mining and local organic fuel burning. However, the levels of NAP in Lomonosovfonna compared with values in Agassiz Ice Cap suggest that, for NAP at least, these sources are not significant. This is also consistent with directions of advected air masses across Svalbard (Niedzwiedz, 1997). In winter and spring, 63.1\% of air masses come from the northeast, east, southeast, north and northwest directions where there are no local sources; only $13.9 \%$ of the winter and spring air comes from directions of local sources. Rose and others (in press) have studied PAH concentrations in sediments from lakes on the western coast of Spitsbergen (downwind of the sources). They find higher concentrations at the site closest to Longyearbyen (about $15 \mathrm{~km}$ away), but no trend with distance in the PAH concentrations at five other sites $60-200 \mathrm{~km}$ away from Longyearbyen. This is evidence that local sources play some role on Svalbard, but probably this is more important for high-molecular-weight $\mathrm{PAH}$, in low-altitude lakes that are close to, and downwind of, coal burning, than for NAP at the high-elevation Lomonosovfonna glacier site.

In future we plan to study the flyash record in the ice core, which we hope will provide more insight into source and transport processes of PAHs. More work on several different organic compounds on the same Svalbard glacier is also in progress. Based on our work, we believe that some ice cores from Svalbard are good archives for studying the environmental pollution history.

\section{AGKNOWLEDGEMENTS}

We are grateful to all members of the Lomonosovfonna icecoring project. The Finnish Forest Research Institute (Rovaniemi) provided facilities for processing the ice samples, and Juvegroup Oy (Rovaniemi) did the $\mathrm{PAH}$ analysis. M. K. Hermanson provided valuable comments on earlier versions of the paper, and R. M. Koerner provided an excellent review that significantly improved the paper. We are grateful to K. Azuma for handling our paper so efficiently. A. Igesund prepared Figure 1. Financial support came from The Finnish Academy, The Finnish Snow and Ice graduate school, Norwegian Polar Institute and the Nordic Arctic Research Programme of the Nordic Minister Council.

\section{REFERENGES}

Arlof, T. 1996. Svalbards historie 1596-1996. Oslo, Aschehoug and Co.

Baek, S. O., R. A. Field, M. E. Goldstone, P.W. Kirk and J. N. Lester. 1991. A review of atmospheric polycyclic aromatic hydrocarbons: sources, fate and behavior. Water, Air, Soil Pollut., 60 (3-4), 279-300.

Barrie, L. A. and 7 others. 1992. Arctic contaminants: sources, occurrence and pathways. Sci. Total Environ., 122(1-2), 1-74.

Bernhoft, A., Ø. Wiig andJ. U. Skaare. 1997. Organochlorines in polar bears (Ursus maritimus) at Svalbard. Environ. Pollut., 95(2), 159-175.

Davies, T. D., C. E. Vincent and P. Brimblecombe. 1982. Preferential elution of strong acids from a Norwegian ice cap. Nature, 300(5888), 161-163.

Isaksson, E. and 14 others. 2001. A new ice-core record from Lomonosovfonna, Svalbard: viewing the 1920-97 data in relation to present climate and environmental conditions. F. Glaciol., 47(157), 335-345.

Jaffrezo, J. L., P. Masclet, M. P. Clain, H. Wortham, S. Beyne and H. Cachier. 1993. Transfer function of polycyclic aromatic hydrocarbons from the atmosphere to the polar ice: 1 . Determination of atmospheric concentrations at Dye 3, Greenland. Atmos. Environ., Ser. A, 27(17-18), 2781-2785.

Jaffrezo, J. L., M. P. Clain and P. Masclet. 1994. Polycyclic aromatic hydrocarbons in the polar ice of Greenland: geochemical use of these atmospheric tracers. Atmos. Environ., 28(6), 1139-1145.

Jauhiainen, T., J. Moore, P. Perämäki, J. Derome and K. Derome. 1999. Simple procedure for ion chromatographic determination of anions and cations at trace levels in ice core samples. Anal. Chim. Acta, 389(1), 21-29.

Kawamura, K., I. Suzuki, Y. Fujii and O. Watanabe. 1994. Ice core record of polycyclic aromatic hydrocarbons over the past 400 years. Naturwissenschaften, 81(11), 502-505.

Lefohn, A. S., J. D. Husar and R. B. Husar. 1999. Estimating historical anthropogenic global sulfur emission patterns for the period 1850-1990. Atmos. Environ., 33(21), 3435-3444.

Macdonald, R.W. and 28 others. 2000. Contaminants in the Canadian Arctic: 5 years of progress in understanding sources, occurrence and pathways. Sci. Total Environ., 254(2-3), 93-234.

Masclet, P. and V. Hoyau. 1994. Evidence for the presence of polycyclic aromatic hydrocarbons in the polar atmosphere and in polar ice. Analusis, 22(7), M31-M33.

Masclet, P., V. Hoyau, J.-L. Jaffrezo and H. Cachier. 2000. Polycyclic aromatic hydrocarbon deposition on the ice sheet of Greenland. Part I. Superficial snow. Atmos. Environ., 34(19), 3195-3207.

Mulvaney, R., E. C. Pasteur, D. A. Peel, E. S. Saltzman and P.-Y. Whung. 1992. The ratio of MSA to non-sea-salt sulphate in Antarctic Peninsula ice cores. Tellus, 44B(4), 295-303.

Niedzwiedz, T. 1997. Częstość występowania typów cyrkulacji nad Spitsbergen (1951-1995) [Frequency of circulation patterns above Spitzbergen (19511995)]. Problemy Klimatologii Polarnej [Gdynia], 7, 9-16.

Nilsson, A. 1997. Arctic pollution issues: a state of the Arctic environment report. Oslo, AMAP. Arctic Monitoring and Assessment Program.

Nye, J. F. 1963. Correction factor for accumulation measured by the thickness of the annual layers in an ice sheet. F. Glaciol., 4(36), 785-788.

O'Dwyer, J. and 7 others. 2000. Methanesulfonic acid in a Svalbard ice core as an indicator of ocean climate. Geophys. Res. Lett., 27(8), 1159-1162.

Peters, A. J., D. J. Gregor, C. F. Teixeira, N. P. Jones and C. Spencer. 1995. The recent depositional trend of polycyclic aromatic hydrocarbons and elemental carbon to the Agassiz Ice Cap, Ellesmere Island, Canada. Sci. Total Environ., 160-161 (Special Issue), 167-179.

Pohjola, V. A. and 7 others. 2002. Effect of periodic melting on geochemical and isotopic signals in an ice core on Lomonosovfonna, Svalbard. 7 . Geophys. Res., 107(D4), 1-4. (10.1029/2000JD000149.)

Rose, N. L., C. L. Rose, J. F. Boyle and P. G. Appleby. In press. Lake-sediment evidence for local and remote sources of atmospherically deposited pollutants on Svalbard. 7. Paleolimnol.

Röthlisberger, R., M. A. Hutterli, S. Sommer, E. W. Wolff and R. Mulvaney. 2000. Factors controlling nitrate in ice cores: evidence from the Dome $\mathrm{C}$ deep ice core. 7. Geophys. Res., 105(D16), 20,565-20,572.

Tørseth, K., T. Berg, J. E. Hanssen and S. Manø. 1999. Overvåking av langtransportert forurenset luft og nedbor. Atmosforisk tilforsel, 1998. Statlig program for forurensningsovervåking. Kjeller, Norwegian Institute for Air Research. (Rapport 768/99.)

Wakeham, S. G., C. Schaffner and W. Giger. 1980. Polycyclic aromatic hydrocarbons in recent lake sediments. I. Compounds having anthropogenic origins. Geochim. Cosmochim. Acta, 44(3), 403-413.

Wania, F. and D. Mackay. 1993. Global fractionation and cold condensation of low volatility organochlorine compounds in polar regions. Ambio, 22(1), $10-18$

Zedeck, M. S. 1980. Polycyclic aromatic hydrocarbons: a review. F. Environ. Pathol. Toxicol., 3(5-6), 537-567. 